\title{
An inhibitor of Staphylococcus aureus exfoliative toxin
}

\author{
A.A. Al-Sulami, ${ }^{1}$ K.K. Al-Rubiay ${ }^{2}$ and A.M. Affat ${ }^{3}$
}

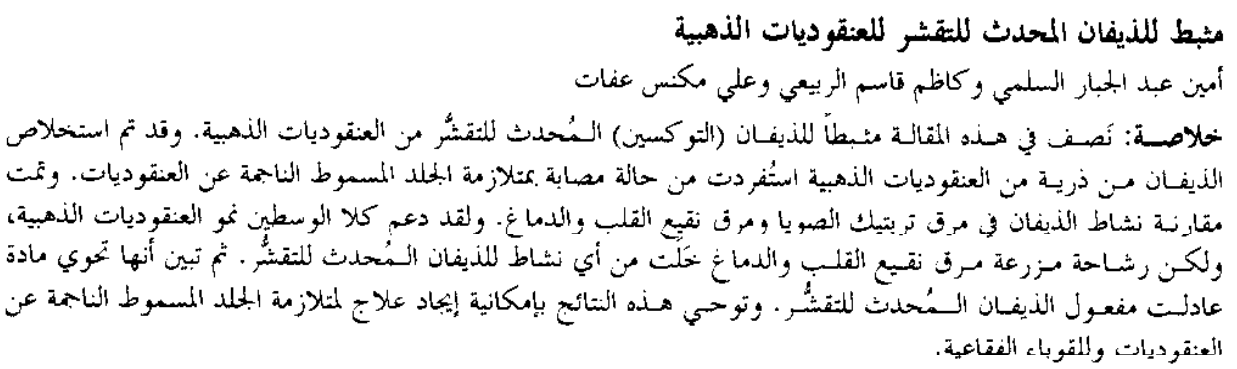

ABSTRACT We describe here an inhibitor of Staphylococcus aureus exfoliative toxin. The toxin was extracted from an $S$. aureus strain isolated from a case of staphylococcus scalded skin syndrome. The activity of the toxin was compared in tryotic soy broth and brain heart infusion hroth Bnth supported growth of $S$. aureus but the culture filtrate of brain heart infusion broth lacked exfoliative toxin activity. Furthermore it appeared to contain a substance that neutralized the action of exfoliative toxin. This suggests the possibility of a treatment for staphylococcal scalded skin syndrome and bullous impetigo.

\section{Un inhibiteur de la toxine exfoliative de Staphylococcus aureus}

RESUME Nous décrivons ici un inhibiteur de la toxine exfoliative de Staphylococcus aureus. La toxine était extraite d'une souche de $S$. aureus isolée sur un cas de syndrome de Lyell staphylococcique. L'activité de la toxine a été comparéc dans le bouillul lypulcase soja et le boullian coeur-cervelle. Les deux boullions favorisaient la croissance de $S$. aureus mais le filtrat de culture du bouillon cceur-cervelle manquait en activite en ce qui concerne la toxine exfoliative. En outre, il semblait contenir une substance qui neutralisait l'action de la toxine exfoliative. Ceci indique qu'il y a une possibilité de traitement du syndrome de Lyetl staphylococcique et de l'impétigo bulleux.

\footnotetext{
'Department of Biology, College of Education, University of Basra, Basra, Iraq. ${ }^{2}$ Department of Dermatology, Basra General Hospital, Basra, Iraq. tDeparment or Medicine, Basra lechnical institute, Basra, Iraq. Received: 14/02/00; accepted: 27/07/00
} 


\section{Introduction}

The sudy of staphylococcal toxin in blistering diseases of the skin arose directly from Lyell's investigation of the. Glasgow uutbreak of staphylococcal impetigo and staphylococcal scalded skin syndrome (SSSS) in 1968-69 [I]. Impetigo is localized and scalding generalized [2]. An outbreak of bullous impetigo occurred in the United States, which included 34 cases of phage type II Stophy/ococcus aureus infection [3]. Arbuthnott and Billcliffe recorded three cases of non-phage group II strain causing SSSS, and nine cases of phage group II [4]. Kaplan et al. reported a high incidence of bullous impetigo in the United States as a result of exfoliative toxin type A, phage type II $S$, aureus [5]. In France, nine cases of SSSS were found by Chan et al. [6]. Al-Ali found $10 \%$ of staphylococci from children with various skin lesions showed signs of exfoliative toxin (ET) effect [7]. Steve showed that the bullous impetigo and SSSS caused by $S$. aureus-producing ET led to clefting of skin in the upper epidermis[8].

It lias been reported that a now type of staphylococcal exfoliative toxin elicited general exfoliation of the epidermis with Nikolsky signs when inoculated into 3-dayold mice and 1-day-old chicks [9]. Recent investigations have produced evidence suggesting that exfoliative toxins induce serine protease activity, although the specific substrate and mode of action are not known for certain [10.1I]. Tanabe et al. found possible receptors for exfoliative toxins produced by $S$. aureus and $S$. hyicus, and that those toxins lost their toxicity by preincubation with ganglioside 4 (GM4)like glycolipid from 1-day-old chicks and suckling mice [12]. In this study, we report the neutralizing effect of a phospholipid on a powerful exfoliative toxin from a local clinical isolate of $S$. aureus.

\section{Methods}

\section{Specimens and sampling}

Skin swabs were collected from 716 patients with different skin diseases attending the outpatients clinic of the Dermatology Department of Basra General Hospital between January and September 1997. Specimens from patients with scalded skin syndrome and bullous impetigo were moistened with brain heart infusion broth (Difco) and transported to the laboratory for immediate processing and culturing on blood agar (Merck) and after 24 hours on mannitol salt agar (Oxoid) for isolation of S. aureus.

\section{Exfoliative toxin-producing $S$. aureus}

Isolates of $S$. aureus were characterized and identified according to Gram stain, morphological characteristics and conventional biochemical tests $[13,14]$. Identified isolates were grown on Difco tryptic soy broth (TSB) and assayed for ET activity in newborn mice [2]. Mice (Mus muscularis), breed $\mathrm{BALB} / \mathrm{c}$, aged $1-7$ days, weight 2-5 $\mathrm{g}$, were divided into two groups, each containing three mice. TSB containing $10^{7}$, $10^{8}$, and $10^{\circ}$ cells $/ \mathrm{mL}$ (McFarland standard) were prepared and one group of mice injected subcutaneously with $0.1 \mathrm{~mL}$ each. The control group of mice was injected with nomal saline. Injected mice were observed for 24 hours for the appearance of Nikolsky signs at the site of injection, i.e. erythema, cyanosis, bullous formation and skin sloughing [/5].

Subsequent experiments concentrated on the culture filtrate of $S$. awreus BS1 
strain isolated from a case of SSSS. The activity of ET of $S$. aureus BS1 was compared both in TSB and brain heart infusion broth (BHIB).

\section{Steps that led to the discovery of an inhibitor of ET}

- Filtrate from $S$. aureus BS1 grown on TSB in shake culture at 140 rpm for 24 hours was injected subcutaneously $(0.1 \mathrm{~mL})$ in rabbits at different sites.

- Filtrate of the sane straill gruwi for 24 hours on BHIB in shake culture was injected $(0.1 \mathrm{~mL})$ into rabbits subcutaneously in different sites.

- Aliquots of BHIB (0.1 mL each) were injected into rabbits either immediately after their injection with $0.1 \mathrm{ml}$ TSB filtrate, or after 1 hour.

- Brain heart infusion medium $(2 \mathrm{~g})$ was dissolved in $10 \mathrm{~mL}$ of absolute alcohol. Two fractions appeared, a supernatant and a precipitate. After evaporating alcohol of the supernatant at room tem- perature, a pasty brownish substance remained. This substance and the precipitate were each dissolved in sterile normal saline. Then each fraction was mixed in $1: 1$ volume with TSB filtrate, i.e. the tuxinteonlaining filtrate, and injected $(0.1 \mathrm{~mL})$ into rabbits subcutaneously.

- In addition, $0.5 \mathrm{~g}$ of the brownish substance was mixed with $2.5 \mathrm{~g}$ of Vaseline to make an ointment. Rabbits were injected each with $0.1 \mathrm{~mL}$ TSB filtratc subcutaneously, and the skin site on each rabbit was rubbed with the ointment, either:

- immediately after the injection; or

- 1 hour later; or

- 24 hours after the injection.

\section{Lecithin}

Different concentrations of lecithin were used as injection or ointment for rabbits receiving ET subcutaneously.

Table 1 Activity of exfoliative toxin produced by Staphylococcus aureus BS1 orown on TSB and $\mathrm{BHIB}$ at $37^{\circ} \mathrm{C}$ and $140 \mathrm{rpm}$

\begin{tabular}{lcccl}
\hline $\begin{array}{l}\text { Age of } \\
\text { culture (hours) }\end{array}$ & $\begin{array}{c}\text { Growth } \\
\text { oD } \mathbf{5 4 0} \mathbf{~ n m}\end{array}$ & $\begin{array}{c}\text { Filtrate } \\
\text { of BHI }\end{array}$ & $\begin{array}{l}\text { Filtrate } \\
\text { of TSB }\end{array}$ & $\begin{array}{l}\text { Skin } \\
\text { reaction }\end{array}$ \\
\hline 4 & 0.3 & - & + & Erythema only \\
6 & 1.0 & - & ++ & Cyanosis, dry skin, \\
10 & 1.5 & - & +++ & eruption, vesicles, \\
12 & 1.9 & - & +++ & bullae, skin sloughing \\
16 & 2.4 & - & ++++ & and separation from the \\
20 & 3.0 & - & +++++ & body, some cases \\
24 & 3.0 & - & +++++ & showed abscess \\
\hline
\end{tabular}

Control: TSB (-), only erythema.

Filtrate of BHIB: $(-)$, only erythema.

$T S B=$ tryptic soy broth.
Controt: BHIB (-), only erythema.

$O D=$ optical density.

$B H I B=$ brain heart infusion broth.

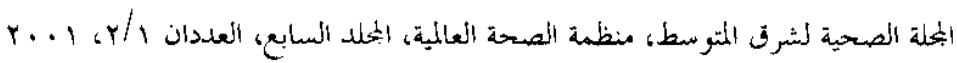


Table 2 Inhibitory effect of injected BHIB on the exfoliative toxin after injecting rabbits with TSB filtrate

\begin{tabular}{lcccl}
\hline $\begin{array}{l}\text { TSB filtrate } \\
(\mathbf{m L})\end{array}$ & $\begin{array}{c}\text { Saline } \\
(\mathbf{m L})\end{array}$ & $\begin{array}{c}\text { BHIB } \\
(\mathbf{m L})\end{array}$ & $\begin{array}{c}\text { No. rabbits } \\
\text { tested }\end{array}$ & Skin reaction \\
\hline 0.1 & 0.1 & Nil & 3 & $\begin{array}{l}\text { Erythema, cyanosis, nodule } \\
\text { then skin dried }\end{array}$ \\
0.1 & Nil & $0.1^{\text {a }}$ & 3 & $\begin{array}{l}\text { Erythema, healing after 1 hour } \\
0.1\end{array}$ \\
Nil & $0.1^{\text {b }}$ & 3 & Erythema, healing after 6 hours
\end{tabular}

-Given immediatoly after injection of TSB filtrate.

'Given 1 hour after injection of TSB fittrate.

$B H I B=$ brain heart infusion broth.

$T S B=$ tryptic soy broth

\section{Results}

Filtrates from cultures of different cell densities showed no activity of ET when $S$. aureus BS1 was grown on BHIB, but parallel growtl on TSB clearly revealed the activity of the toxin on injection into young mice $(0.1 \mathrm{~mL}$ each density). Animals showed erythema and cyanosis, skin eruption, vesicles, bullae, sloughing of the skin and separation from the body, and in some cases, abscess (Table 1). Skin sections of animals injected with saline showed no pathological change, whereas sections of those injected with $S$. aureus BSI or its culture filtrate, TSB filtrate, showed typical intraepidermal cleavage caused by acantholysis of superficial epidermal cells.

The sites injected with TSB filtrate followed immediately, or after I hour, by injection with $\mathrm{BHIB}$, remained normal -- i.e. no signs on the skin, except erythema that disappeared within 1-6 hours (Table 2). There was also no effect of ET on the sites injected with TSB filtrate, as long as the cxtracted pasty brownish substance was mixed with TSB filtrate before injection, or used as an ointment (Table 3 ).

Table 3 Inhibitory effect of the BHIB-alcohol-extracted brownish substance on the exfoliative toxin when applied as an ointment, after injecting rabbits with TSB filtrate

\begin{tabular}{lcccc}
\hline $\begin{array}{l}\text { TSB } \\
\text { filtrate } \\
(\mathbf{m L})\end{array}$ & $\begin{array}{c}\text { Saline } \\
(\mathbf{m L})\end{array}$ & $\begin{array}{c}\text { BHIB extract } \\
\text { (0.5 g/2.5 } \\
\text { Vaseline) }\end{array}$ & $\begin{array}{c}\text { No. rabbits } \\
\text { tosted }\end{array}$ & Skin reaction \\
\hline 0.1 & 0.1 & Nil & 3 & Cyanosis, nodule then skin dried \\
0.1 & Nil & $Y^{3}$ & 3 & Erythema oinly, healing after 1 howr \\
0.1 & Nil & Yes $^{b}$ & 3 & Erythema, nodule then healing
\end{tabular}

Applied immediately after injection of TSB filtrate.

Applieu 1 hour arler injecifor of TSE millidte.

$B H I B=$ brain heart infusion broth.

$T S B=$ tryptic soy broth. 
Table 4 Inhibitory effect of injected lecithin $(50 \mathrm{mg} / \mathrm{mL})$ on the activity of exfoliative toxin after injection of rabbits with TSB filtrate

\begin{tabular}{|c|c|c|c|c|}
\hline $\begin{array}{l}\text { TSB filtrate } \\
(\mathrm{mL})\end{array}$ & $\begin{array}{l}\text { Saline } \\
\text { (mL) }\end{array}$ & $\begin{array}{l}\text { Lecithin } \\
\text { (mL) }\end{array}$ & $\begin{array}{l}\text { No. } \\
\text { rabbits } \\
\text { tested }\end{array}$ & Skin reaction \\
\hline 0.1 & 0.1 & Nil & 3 & Cyanosis, nodule and bullous eruption \\
\hline 0.1 & Nil & $0.1^{\mathrm{a}}$ & 3 & Erythema only, healing after 1 hour \\
\hline 0.1 & Nil & $0.1^{b}$ & 3 & $\begin{array}{l}\text { Erythoma, pooling of afferoted stin } \\
\text { then healing }\end{array}$ \\
\hline
\end{tabular}

${ }^{a}$ Given immediately after injection of TSB filtrate.

'Given $1 \mathrm{hom}$ after injection of TSB filtrato.

$T S B=$ tryptic soy broth.

Application of lecithin by injection or as an ointment immediately or 1 hour after injecting the rabbits with TSB filtrate, showed a neutralizing effect on ET similar to what was seen with BHIB or the pasty brownish substance from BHIB (Tables 4 and 5). Meanuhile, preincubation of the toxin either with lecithin or BHIB, as well as the follow-up injections, were more effective than the ointment. However, increasing the concentration of lecithin in the ointment up to $200 \mathrm{mg} / \mathrm{g}$ of Vaseline was more effective in neutralizing the action of ET. Aliquots of $0.1 \mathrm{~mL}$ TSB filtrate represent a sub-lethal dose. Injection of rabbits with a dose of $0.2 \mathrm{~mL}$ TSB filtrate and then Immediately rubbing the injected area with $100 \mathrm{mg}$ lecithin/g Vaseline was not sufficient to save the animal from death. Postmortem examination indicated that viscera congested, cyanosis took place, there was liver enlargement with cyanosis, ecchymosis in the intestine, gall bladder enlargement and non-absorbed food material. Clinically, the animal showed depression, congested eye and anorexia.

ET purified by combination with ammonium sulfate, gel filtration and ionexchange gave one band on gel electrophoresis. It showed the same signs of action on suckling mice and was also neutralized by lecithin.

\section{Discussion}

During this study, a scarch was conducted to find an inhibitor of ET. Early signals came from the fact that although BHIB supported the growth of $S$ aureus, its

Table 5 Inhibitory effect of lecithin ointment on the activity of oxfoliative toxin aftor injeotion of rabbits with TSB filtrate

\begin{tabular}{lccl}
\hline $\begin{array}{l}\text { TSB } \\
\text { filtrate } \\
(\mathbf{m L})\end{array}$ & $\begin{array}{c}\text { Lecithin } \\
\text { ointment (mg/g } \\
\text { Vaseline) }\end{array}$ & $\begin{array}{c}\text { No. rabbits } \\
\text { tested }\end{array}$ & Skin reaction \\
\hline 0.1 & 100 & 3 & Erythema, one small vesicle each, no cyanosis \\
0.1 & 200 & 3 & No erythema, nomal skin \\
\hline
\end{tabular}

${ }^{2}$ The ointment was applied immeciately after injection of the TSB filtrate.

TSB = tryptic soy broth

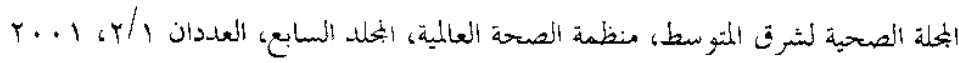


culture filtrate lacked ET activity. In addition, preparation of BHIB used as injection into rabbits inhibited exfoliation and appearance of Nikolsky signs. Therefore, it was thought that $\mathrm{BHIB}$, in contrast to TSB, contained a substance that somehow neutralizeed the action of ET.

It was shown that the pasty brownish substance from the alcohol fraction of BHI possessed the neutralizing effect on ET, which implies that a lipid component is more likely to he the neutralizer or inhibitor of ET. The introduction of lecithin as an inhibitory substance of ET was inferred from these results and from other findings $[12,16]$, coupled with the fact that lecithin inhibits another toxin of $S$. aureus, the delta haemolysin [17].
Kondo described the partial characterization of an inhibitor of ET extracted from mouse skin with sodium dodecyl sulfate [16]. Also, a possible receptor has been found for ET, designated GM4-like glycolipid; it has been reported that $S$. hyicus and $S$. aureus exfoliative toxins lost their toxicity on preincubation with GM4-like glycolipid from 1-day-old chicks and suckling mice respectively [12]. Injecting or rubbing the experimental animal with lecithin showed effective inhibition of ET. It seems that BHI does not inhibit the synthesis of ET, but rather ET loses its activity due to the presence of a lipid component. Similarly, lecithin renders ET ineffective by an, as yet, unknown mechanism.

\section{Roforoncos}

1. Lyell A, Dick HM, Alexander JO. Outbreak of toxic epidermal necrolysis associated with staphylococci. Lancet, 1969, 1(7599):787-9.

2. Melish ME, Glasgow LA. Staphylococcal scalded skin syndrome: the expanded clinical syndrome. Journal of pediatrics, 1971, 78:958 67.

3. Albert $S$ et al, Bullous impetigo due to group II Staphylococcus aureus. American journal of discases of children, 1970, 120:110-3.

4. Arbuthnott JP, Billcliffe B. Qualitative and quarititalive meltuds for detecting staphylococcal epidermolytic toxin. Journal of medical microbiology, 1976, 9:191201.

5. Kaplan MH et al. Importance of exfoliatin toxin A production by Staphylococcus surous strains isolated from clustered epidemics of neonatal pustulosis. Jour- nal of clinical microbiology, 1986 , 23:83-91.

6. Chan $\mathrm{HL}$ et al. The incidence of erythema multiforme, Stevens-Johnson syndrome and toxic epidermal necrolysis. A population based study with particular reference to reactions caused by drugs among outpatients. Archives of dermatology, 1990, 126:43-7.

7. Al-Ali SR. A study on staphylococci producing scaldod skin syndromo isolatod from children [MSc thesis]. University of Baghdad, Iraq, 1993.

8. Steve H. Blistering disorders. New othical New Zealand's journal practitioner drug treatment, 1994, 31:55-65.

9. Sato $\mathrm{H}$ et al. A new type of staphylococcal exfoliative toxin from a Staphylococcus aureus strain isolated from a horse with phlegmon. Infection and immunity. 1994, 62:3780-5.

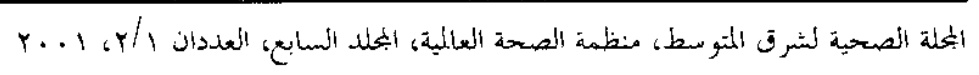


10. Ladhani S et al. Staphylococcal scaided skin syndrome: exfoliative toxin A (ETA) induces serine protease activity when combined with A431 celis. Acta paediatrica, 1999, 88:776-9.

11. Vath $G M$ et al. The crystal structure of exfoliative toxin $B$ : a superantigen with enzymatic activity. Biochemistry, 1999, 38:10239-46.

12. Tanabe $T$ et al. Possible receptor for exfoliative toxins produced by Staphylococcus hyicus and Staphylococcus aureus. infection and immunity, 1995, 64:1591-4.

13. Kloos WE, Bannerman TL. Staphylococcus and micrococcus. In :Murray $\mathrm{rR}$ et al., eds. Manual of clinical microbiology, 6th ed. Washington DC, American Society for Micrabiology, 1995.
14. Kloos WE, Schleifer KH. Staphylococcus. In: Holt JG et al, eds. Bergey's manual of systematic bacteriology, Vol. 2. Baltimore, Williams and Wilkins Company, 1986.

15. Rogolsky M, Wiely BB, Glasgow LA. Phage group || staphylococcal strains with chromosomal and extrachromosomal genes for exfoliative toxin production. Infecifon and immunity, 1970, 13:44-52.

16. Kondo I. Research on receptor for staphylococcal exfoliatin. In: Jerliszewicz $\mathrm{J}$, ed. Proceedings of the 4th intemational symposium on staphylococci and staphylococcal infections. Stuttgart, 1980.

17. Whitelaw DD, Birkbeck TH. Inhibition of staphylococcal delta hemolysin by serum lipoproteins. FEMS microbiology lottors, 1978, 3:336-8.

\section{Mote from the Editor}

We wish to draw the kind attention of our potential authors to the importance of applying the editorial requirements of the EMHJ when preparing their manuscripts for submission for publication. These provisions can be secn in the Guidelines for Author's, which are published at the end of every issue of the Journal. We regret that we are unable to accept papers that do not conform to the editorial requirements.

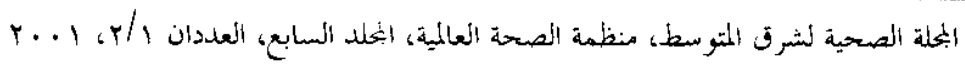

